\title{
In silico identification of novel immunostimulating phytochemicals with acetylcholinesterase inhibition activity from Piper betle L. and Vitex negundo L. for the treatment of Alzheimer's disease (AD)
}

\author{
Abubucker Peer Mohideen \\ Department of Basic Medical Sciences, College of Medicine, Prince Sattam bin Abdulaziz University, Al-Kharj-11942, Saudi Arabia
}

\section{Article Info \\ Article history \\ Received 25 April 2021 \\ Revised 29 May 2021 \\ Accepted 30 May 2021 \\ Published online 30 June 2021}

\section{Keywords}

Neurodegenerative disorders

Alzheimer's disease

Acetylcholinesterase

Piper betle L.

Vitex negundo $\mathrm{L}$.

Molecular docking

ADMET analysis

\begin{abstract}
Alzheimer's disease (AD) is the most prevalent type of dementia and a worsening neurodegenerative disease. Drugs for AD has severe side effects and the development of new anti-AD medicines are in high demand. The use of medicinal herbs and plants in the treatment of a variety of diseases has become increasingly common in recent years. Thus, the present study focuses on identification of novel phytochemical compounds from Piper betle L. and Vitex negundo L. showing anti-AD by in silico analysis. Human acetylcholinesterase is used as the target enzyme. The compounds were preliminarily screened for druglikeness analysis (RO5). Molecular docking, protein-ligand interaction and ADMET analysis were carried out to identify the potential compounds. Total of 42 compounds were identified and 34 compounds showed druglikeness properties. About 22 compounds showed higher binding energies, i.e., >-7 Kcal $/ \mathrm{mol}$ and these compounds were analysed for interactions on binding sites of AChE. ADMET analysis was performed and compared with a standard drug rivastigmine. Total of 20 novel compounds, Piperine in $P$. betle, beta-Sitosterol, beta-Caryophyllene, Acerosin, Casticin, Mearnsetin, 5, 3'Dihydroxy-6,7,4'-trimethoxyflavanone, 5,3'-Dihydroxy-7,8,4'-trimethoxyflavanone, Detetrahydroconidendrin, Negundin A, Negundin B, Vitrofolal E, Vitrofolal F, Vitedoamine A, Vitedoin A, Vitedoin B, Vitexdoin A, Vitexdoin B, Vitexdoin C, Vitexdoin D and Vitexdoin E present in Vitex negundo were identified to be the effective acetylcholinesterase inhibitors. These compounds have potential to be developed as anti-AD drugs with higher efficacy and lesser side effects.
\end{abstract}

\section{Introduction}

Alzheimer's disease (AD) is the most prevalent type of dementia and a worsening neurodegenerative disease that causes patients to experience cognitive dysfunction, psychosis, hyperactivity, physical aggression, and anxiety (Lane et al., 2018). The global dementia population was estimated to be 35.6 million in 2010 , and it is expected to almost doubled over the past 20 years, to be nearly 65.7 million in 2030 and will be 115.4 million in 2050. Every year, almost 7.7 million new cases of dementia are diagnosed worldwide, meaning one case every four seconds. Most of the rise will occur in developing countries, with China, India, and their south Asian and western Pacific neighbours seeing the highest growth in the elderly population. According to the United Nations, Europe had an estimated 10 million disease cases in 2010, and this number is expected to grow to 14 million by 2030 . Looking at these statistics, it is obvious that something has to be done now. As the world's population ages, Alzheimer's disease $(\mathrm{AD})$ has become a significant public health issue. People aged 60 and up are expected to make up $22 \%$ of the global population by 2050 , with four-fifths residing in Asia, Latin America or Africa (Prince et al., 2015).

Corresponding author: Dr. Abubucker Peer Mohideen
Assistant Professor, Department of Basic Medical Sciences, College
of Medicine, Prince Sattam bin Abdulaziz University, Al-Kharj-
11942 , Saudi Arabia
E-mail: peermdnnn@gmail.com
Tel.: +96-6553201774

Copyright $\odot 2021$ Ukaaz Publications. All rights reserved.

Email: ukaaz@yahoo.com; Website: www.ukaazpublications.com
While the exact immunological event that triggers Alzheimer's disease $(\mathrm{AD})$ has yet to be identified, some studies suggest that $\mathrm{AD}$ as an autoimmune disease. A common denominator associated with various levels of dementia, including Alzheimer's disease, is agerelated vascular disorders, which have an impaired blood brain barrier (BBB). A crucial discovery recently revealed not only the unusual existence of immunoglobulin detection in the subarachnoid space of $\mathrm{AD}$ tissues, but also that certain neurons with degenerative, apoptotic features contained these vascular-derived antibodies. In addition, classical complement constituents $\mathrm{C} 1 \mathrm{q}$ and $\mathrm{C} 5 \mathrm{~b}-9$ were found in these Ig-positive neurons, which were also spatially more correlated with reactive microglia than the Ig-negative neurons. Thus, the increased presence of anti-neuronal autoantibodies in the serum, whose significance had previously been overlooked, could be without pathological impact before the BBB is disrupted, allowing the autoantibodies' deleterious effects to reach their targets. As a result, these findings point to autoimmunity-induced cell death in Alzheimer's disease (D'Andrea, 2005; Schnabel, 1993).

Acetylcholinesterase (AChE) inhibitors including rivastigmine, galantamine and donepezil block AChE's effects in the synapse, causing, bradycardia, nausea, vomiting, anorexia and diarrhoea as side effects. Memantine is an N-methyl D-aspartate potent inhibitor that has been approved for the treatment of moderate-to-severe Alzheimer's disease in Europe and the United States, but it can cause headaches, dizziness, nausea, insomnia, constipation, mild allergies and auditory hallucinations. The development of new anti- 
$\mathrm{AD}$ medicines is in high demand. The use of medicinal herbs and plants in the treatment of a variety of diseases has become increasingly common in recent years. According to the World Health Organization (WHO), 85 per cent to 90 per cent of the global population depend on natural medicine to handle their healthcare needs (Das et al., 2017; Kareti and Pharm, 2020).

Therefore, the present study concentrates on identification of novel phytochemical compounds from P. betle and $V$. negundov showing anti-Alzheimer's disease by in silico analysis. Human acetylcholinesterase is used as the target enzyme. The compounds were preliminarily screened for druglikeness analysis based on Lipinski's rule of Five (RO5). Molecular docking, protein-ligand interaction and ADMET analysis were carried out.

\section{Materials and Methods}

\subsection{Preparation of target proteins}

The Human acetylcholinesterase (PDB ID: 4M0E) was used as target proteins in this research and the 3D structures were retrieved from the Protein Data Bank (http://www.rcsb.org/). Using PyMol tool, the protein is visualized and then the protein bound water molecules, ligands and co-crystal ligands were eliminated (Figure 1). Further, protein was prepared in Auto Dock Tools, an open source software by introducing charges and energy minimization in Swiss PDB viewer and then converted to pdbqt format.

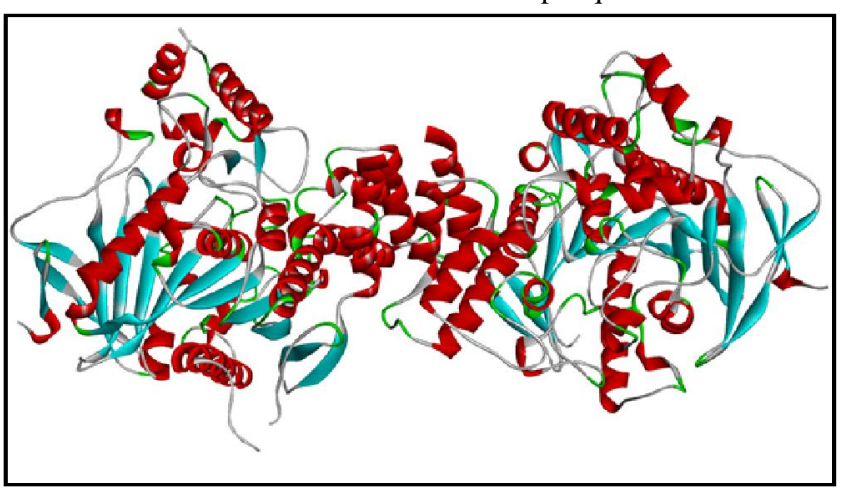

Figure 1: 3D structures of the human acetylcholinesterase.

\subsection{Selection and preparation of ligands}

The phytochemical compounds present in P. betle and V. negundo were identified and retrieved using KNApSAck database (http:// www.knapsackfamily.com/KNApSAcK/). Total of 42 phytochemical compounds were used for the study. The preparation of ligand is carried out by detecting their torsion root, assigning charges, correcting the torsion angle, optimizing using UFF (universal force field) and then finally converted into pdbqt format to generate $3 \mathrm{D}$ atomic coordinates of the molecules (Rédei, 2008).

\subsection{Identification of active sites of target proteins}

Potential docking analysis requires accurate assessment of the active site. The amino acids in the active pocket site formation for target proteins were identified using the CASTp server (Computed Atlas for Surface Topography) (Sanjay Prasad and Shanthi, 2020; Tian et al., 2018). CASTp is a simple and useful online tool to analyze the protein topology and active site pockets. Active site determination is a vital part to set the grid box before docking.

\subsection{Screening of the of the ligands based on druglikeness}

The druglikeness of the compounds are evaluated using the online server Swiss ADME (http://swissadme.ch/index.php). Druglikeness of a compound is a necessary parameter to validate them as potential ligands against therapeutic targets (Daina et al., 2017). 42 phytochemical compounds were screened using the Lipinski's Rule of Five and compounds showing druglikeness were used for docking studies.

2.5 Molecular docking and protein-ligand interaction analysis

The molecular docking of all the compound libraries was conducted using the PyRx tool by autodock wizard as the docking engine. Throughout, the docking process the ligands were assumed to be flexible and the protein was expected to be rigid. The grid parameter configuration file is generated using the grid box for $4 \mathrm{M} 0 \mathrm{E}(\mathrm{x}=0.07$, $y=-44.36, z=11.67$ ) in PyRx, respectively (Dallakyan and Olson, 2015). After docking, the highest biding energy (most negative) was identified as the ligand with maximum binding affinity. The ligands exhibiting higher binding energy $(<-7 \mathrm{Kcal} / \mathrm{mol})$ were recognized and the ligand-protein interaction on the binding sites were analysed using Biovia Drug discovery studio 2020.

\subsection{ADMET analysis of the selected ligands}

ADMET analysis involves evaluation of absorption, distribution, metabolism, excretion and toxicity levels of the selected compounds using online based algorithms. There are numerous online database and offline software applications which helps in predicting the drug candidates behaviour. In this study, we have used admet SAR (Cheng et al., 2012) for ADMET predictions. The compounds showing higher binding energies were examined for its Human intestinal absorption, in vivo blood-brain barrier penetration, in vitro Caco-2 cell permeability, CYP450 2C9 substrate and toxicity parameters like mutagenicity by AMES test and carcinogenicity on rat were determined. Broad spectrum antibacterial drugs, amoxicillin and ciprofloxacin are used as a standard drug to compare with the compounds.

\section{Results}

\subsection{Druglikeness profiling of compounds}

The molecular and physical properties of the compounds play a key role in the identification of certain agents as a drug candidate. The compounds were filtered via Lipinski's five (Ro5) law to predict druglikeness. Lipinski's rule of five (Ro5) is a valuable parameter for determining the molecular properties of drug compounds and to estimate the essential pharmacokinetic parameters such as absorption, distribution, metabolism, and excretion for drug design and development (Lipinski et al., 2012). From this analysis, 42 out of 36 phytochemical compounds satisfied Lipinski's rule of five and the values were presented in the Table 1.The screened 46 compounds were subjected to molecular docking analysis.

\subsection{Binding site analysis and Molecular docking}

Active site pocket in Human acetylcholinesterase was determined using CASTp. CASTp is a web-based tool to determine the amino acid residues in the active pocket of the proteins. CASTp results are depicted in Figure 2 for Human acetylcholinesterase. From CASTp results, only the amino acids in the active site and their positions are listed as Table 2. Grid box were generated covering the binding sites of the target protein. 


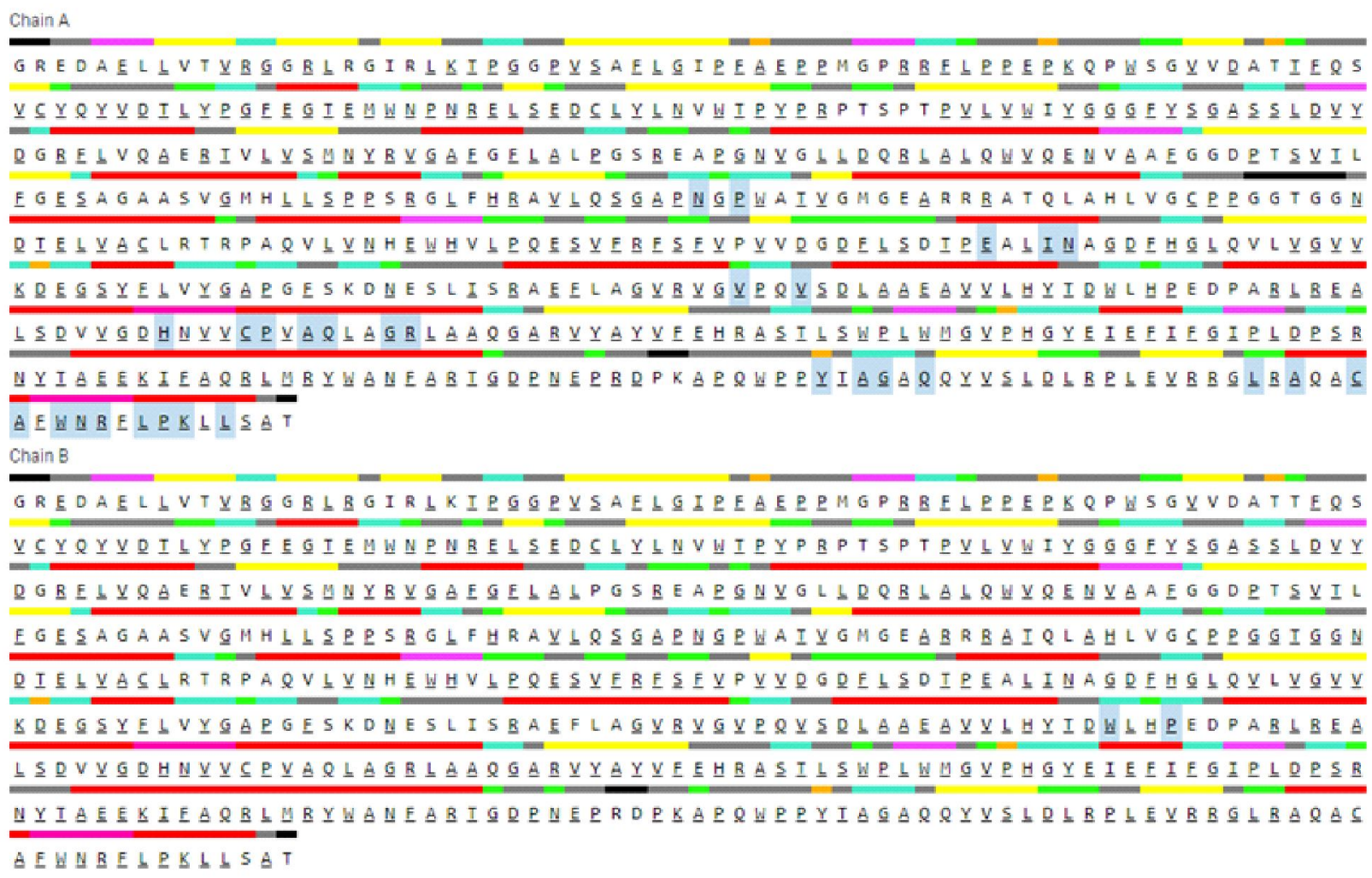

Figure 2: Binding sites of human acetylcholinesterase analysed using CASTp.

Table 1: Compounds showing druglikeness properties

\begin{tabular}{|c|l|c|l|}
\hline S.No. & Compound name & S.No. & Compound name \\
\hline 1 & Carvacrol & 18 & Mearnsetin \\
\hline 2 & Eugenol & 19 & (+)-Lyoniresinol \\
\hline 3 & Chavicol & 20 & $\begin{array}{l}5,3^{\prime} \text {-Dihydroxy-6,7,4'- } \\
\text { trimethoxyflavanone }\end{array}$ \\
\hline 4 & Octadecanoic acid & 21 & $\begin{array}{l}5,3^{\prime} \text {-Dihydroxy-7,8,4'- } \\
\text { trimethoxyflavanone }\end{array}$ \\
\hline 5 & Triacontane & 22 & $\begin{array}{l}\text { Detetrahydroconi- } \\
\text { dendrin }\end{array}$ \\
\hline 6 & Piperine & 23 & Negundin A \\
\hline 7 & Methyl chavicol & 24 & Negundin B \\
\hline 8 & beta-Sitosterol & 25 & Vitrofolal E \\
\hline 9 & Cepharadione A & 26 & Vitrofolal F \\
\hline 10 & Dotriacontanoic acid & 27 & Vitedoamine A \\
\hline 11 & Piperlonguminine & 28 & Vitedoin A \\
\hline 12 & (+)-alpha-Pinene & 29 & Vitedoin B \\
\hline 13 & 4 -hydroxybenzoic acid & 30 & Vitexdoin A \\
\hline 14 & Camphene & 31 & Vitexdoin B \\
\hline 15 & beta-Caryophyllene & 32 & Vitexdoin C \\
\hline 16 & Acerosin & 33 & Vitexdoin D \\
\hline 17 & Casticin & 34 & Vitexdoin E \\
\hline \hline
\end{tabular}

Table 2: Amino acid residues in the active sites

\begin{tabular}{|c|l|l|}
\hline S.No & Target protein & $\begin{array}{l}\text { Amino acid residues in } \\
\text { binding sites }\end{array}$ \\
\hline \multirow{2}{*}{1} & Human acetylcholi- & A: ASN-233, PRO-235, GLU-313, \\
& ILE-316, ASN-317, VAL-367, \\
& ID: 4M0E) & VAL-370, HIS-405, CYS-409, \\
& & PRO-410, ALA-412, GLN-413, \\
& GLY-416, ARG-417, TYR-503, \\
& & ALA-505, GLY-506, 508-GLN, \\
& & LEU-524, ALA-526, CYC-529, \\
& & ALA-530, TRP-532, ASN-533, \\
& & ARG-534, LEU-536, LEU-536, \\
& & PRO-537, LYS-538, LEU-540B: \\
& & TRP-385, PRO-388 \\
\hline
\end{tabular}

PyRx was used for performing docking analysis for all 46 compounds against their target proteins tyrosyl-tRNA synthetase and DNA gyrase. Binding energies of the compounds were analyzed and the compounds showing higher binding energy $(<-7.0 \mathrm{Kcal} / \mathrm{mol})$ against the target enzyme acetyl cholinesterase were identified. 34 compounds showed significant binding energy $(<-7.0 \mathrm{Kcal} / \mathrm{mol})$ for both the targets and the compounds are shown in the Table 3.

\subsection{Protein-ligand interaction analysis}

The best-docked compounds were further analyzed for binding interactions with amino acid residues using Biovia Accelrys Discovery Studio Visualizer software. Bonding type, number of hydrogen bonds and hydrophobic interactions are a very important determinant of protein-ligand interactions as well as binding affinity. 
Table 3: Binding energies of the compounds against the acetylcholinesterase

\begin{tabular}{|c|c|c|}
\hline S. No. & Compound name & $\begin{array}{c}\text { Binding } \\
\text { energies } \\
\text { (Kcal/mol) }\end{array}$ \\
\hline 1 & Carvacrol & -5.9 \\
\hline 2 & Eugenol & -6.4 \\
\hline 3 & Chavicol & -5.8 \\
\hline 4 & Octadecanoic acid & -4.9 \\
\hline 5 & Triacontane & -4.2 \\
\hline 6 & Piperine & -7.0 \\
\hline 7 & Methyl chavicol & -5.5 \\
\hline 8 & beta-Sitosterol & -7.8 \\
\hline 9 & Cepharadione A & -7.5 \\
\hline 10 & Dotriacontanoic acid & -5.3 \\
\hline 11 & Piperlonguminine & -6.4 \\
\hline 12 & $(+)$-alpha-Pinene & -5.7 \\
\hline 13 & 4-hydroxybenzoic acid & -5.9 \\
\hline 14 & Camphene & -5.3 \\
\hline 15 & beta-Caryophyllene & -7.0 \\
\hline 16 & Acerosin & -7.1 \\
\hline 17 & Casticin & -7.0 \\
\hline 18 & Mearnsetin & -7.1 \\
\hline 19 & $(+)$-Lyoniresinol & -6.5 \\
\hline 20 & $\begin{array}{l}5,3 \text { '-Dihydroxy- } 6,7,4 \text { '-trimethoxy- } \\
\text { flavanone }\end{array}$ & -7.3 \\
\hline 21 & $\begin{array}{l}5,3 \text { '-Dihydroxy-7,8,4'-trimethoxy- } \\
\text { flavanone }\end{array}$ & -7.3 \\
\hline 22 & Detetrahydroconidendrin & -7.9 \\
\hline 23 & Negundin A & -8.1 \\
\hline 24 & Negundin B & -7.2 \\
\hline 25 & Vitrofolal E & -7.4 \\
\hline 26 & Vitrofolal F & -7.2 \\
\hline 27 & Vitedoamine A & -7.8 \\
\hline 28 & Vitedoin A & -7.0 \\
\hline 29 & Vitedoin B & -7.2 \\
\hline 30 & Vitexdoin A & -7.4 \\
\hline 31 & Vitexdoin B & -7.4 \\
\hline 32 & Vitexdoin C & -7.4 \\
\hline 33 & Vitexdoin D & -7.5 \\
\hline 34 & Vitexdoin E & -7.3 \\
\hline
\end{tabular}

The number of hydrogen bonds formed and amino acids involved in the interactions are tabulated in Table 4. The hydrogen bonds and other hydrophobic interactions of the ligands on the binding sites of the target proteins were shown in the Figures 3 to 24 . All the 22 compounds showed $\mathrm{H}$-bond formation on binding sites of the target proteins except beta-caryophyllene. This compound failed to show $\mathrm{H}$-bond on binding sites of Human acetylcholinesterase. Therefore, the remaining 21 compounds were subjected to ADMET analysis to find out significant compounds for development of novel drugs for treatment of $\mathrm{AD}$.

Table 4: Protein-ligand interactions

\begin{tabular}{|c|c|c|c|}
\hline \multirow[b]{2}{*}{ S.No. } & \multirow[b]{2}{*}{ Compound name } & \multicolumn{2}{|c|}{$\begin{array}{l}\text { Ligand interaction on binding } \\
\text { sites of target protein }\end{array}$} \\
\hline & & $\begin{array}{c}\text { No. of } \\
\text { H-bond }\end{array}$ & $\begin{array}{l}\text { Binding amino } \\
\text { acid residue }\end{array}$ \\
\hline 1 & Piperine & 2 & TYR-503, ARG-417 \\
\hline 2 & beta-Sitosterol & 1 & GLN-413 \\
\hline 3 & Cepharadione A & 1 & HIS-405 \\
\hline 4 & beta-Caryophyllene & - & - \\
\hline 5 & Acerosin & 4 & $\begin{array}{l}\text { GLN-413, ARG-417, } \\
\text { TYR-503, ARG-534 }\end{array}$ \\
\hline 6 & Casticin & 2 & GLU-313, LYS-538 \\
\hline 7 & Mearnsetin & 2 & HIS-405, GLN-413 \\
\hline 8 & $\begin{array}{l}\text { 5,3'-Dihydroxy-6, } \\
7,4^{\prime} \text {-trimethoxy } \\
\text { flavanone }\end{array}$ & 1 & TYR-503 \\
\hline 9 & $\begin{array}{l}5,3^{\prime} \text {-Dihydroxy-7, } \\
8,4^{\prime} \text {-trimethoxy- } \\
\text { flavanone }\end{array}$ & 1 & GLU-313 \\
\hline 10 & $\begin{array}{l}\text { Detetrahydroconi- } \\
\text { dendrin }\end{array}$ & 2 & $\begin{array}{l}\text { ASN-233, GLN-413, } \\
\text { ASN-533 }\end{array}$ \\
\hline 11 & Negundin A & 2 & GLU-313, ASN-533 \\
\hline 12 & Negundin B & 3 & $\begin{array}{l}\text { GLU-313, HIS- } 405 \text {, } \\
\text { ASN-533 }\end{array}$ \\
\hline 13 & Vitrofolal E & 4 & $\begin{array}{l}\text { GLU-313, HIS-405, } \\
\text { GLN-413, ASN-533 }\end{array}$ \\
\hline 14 & Vitrofolal F & 1 & HIS-405 \\
\hline 15 & Vitedoamine A & 1 & HIS-405 \\
\hline 16 & Vitedoin A & 2 & TRP-532, ASN-533 \\
\hline 17 & Vitedoin B & 1 & HIS-405 \\
\hline 18 & Vitexdoin A & 1 & PRO-235 \\
\hline 19 & Vitexdoin B & 1 & GLU-313 \\
\hline 20 & Vitexdoin C & 1 & GLN-413 \\
\hline 21 & Vitexdoin D & 1 & HIS-405 \\
\hline 22 & Vitexdoin E & 2 & HIS-405, TRP-532 \\
\hline
\end{tabular}


Table 5: ADME analysis of the selected compounds

\begin{tabular}{|c|c|c|c|c|c|c|}
\hline S.No. & Compound name & $\begin{array}{c}\text { In vivo blood- } \\
\text { brain barrier } \\
\text { penetration } \\
\text { (C.brain / } \\
\text { C. blood) }\end{array}$ & $\begin{array}{c}\text { Human } \\
\text { intestinal } \\
\text { absorption } \\
(\%)\end{array}$ & $\begin{array}{l}\text { In vitro Caco-2 } \\
\text { cell permeability } \\
(\mathrm{nm} / \mathrm{sec})\end{array}$ & Distribution & CYP450 2C9 \\
\hline 1 & Rivastigmine & 0.99 & 0.99 & 0.77 & 0.82 & 0.84 \\
\hline 2 & Piperine & 0.99 & 1.00 & 0.64 & 0.68 & NS $(0.88)$ \\
\hline 3 & beta-Sitosterol & 0.97 & 1.00 & 0.79 & 0.46 & NS (0.84) \\
\hline 4 & Cepharadione A & 0.91 & 0.98 & 0.65 & 0.42 & NS $(0.80)$ \\
\hline 5 & Acerosin & 0.68 & 0.96 & 0.87 & 0.63 & NS $(0.75)$ \\
\hline 6 & Casticin & 0.59 & 0.98 & 0.89 & 0.79 & NS $(0.78)$ \\
\hline 7 & Mearnsetin & 0.63 & 0.97 & 0.88 & 0.64 & NS $(0.73)$ \\
\hline 8 & $\begin{array}{l}\text { 5,3'-Dihydroxy- } 6,7,4^{\prime} \text { - } \\
\text { trimethoxyflavanone }\end{array}$ & 0.61 & 0.96 & 0.84 & 0.79 & NS $(0.75)$ \\
\hline 9 & $\begin{array}{l}\text { 5,3'-Dihydroxy- } 7,8,4^{\prime} \text { - } \\
\text { trimethoxyflavanone }\end{array}$ & 0.61 & 0.96 & 0.84 & 0.79 & NS $(0.75)$ \\
\hline 10 & Detetrahydroconidendrin & 0.70 & 0.99 & 0.78 & 0.85 & NS $(0.75)$ \\
\hline 11 & Negundin A & 0.63 & 0.98 & 0.71 & 0.81 & NS $(0.74)$ \\
\hline 12 & Negundin B & 0.84 & 0.98 & 0.66 & 0.82 & NS (0.79) \\
\hline 13 & Vitrofolal E & 0.71 & 0.99 & 0.88 & 0.90 & NS $(0.77)$ \\
\hline 14 & Vitrofolal F & 0.65 & 0.99 & 0.87 & 0.87 & NS $(0.79)$ \\
\hline 15 & Vitedoamine A & 0.84 & 1.00 & 0.50 & 0.76 & $\mathrm{NS}(0.76)$ \\
\hline 16 & Vitedoin A & 0.92 & 1.00 & 0.78 & 0.84 & NS $(0.80)$ \\
\hline 17 & Vitedoin B & 0.92 & 0.99 & 0.56 & 0.75 & NS $(0.78)$ \\
\hline 18 & Vitexdoin A & 0.92 & 0.98 & 0.61 & 0.64 & NS $(0.78)$ \\
\hline 19 & Vitexdoin B & 0.96 & 0.99 & 0.61 & 0.82 & NS $(0.78)$ \\
\hline 20 & Vitexdoin C & 0.71 & 0.99 & 0.88 & 0.90 & NS $(0.77)$ \\
\hline 21 & Vitexdoin D & 0.65 & 0.99 & 0.87 & 0.87 & NS $(0.79)$ \\
\hline 22 & Vitexdoin E & 0.65 & 0.99 & 0.87 & 0.87 & NS (0.79) \\
\hline
\end{tabular}

*NS-non substrate

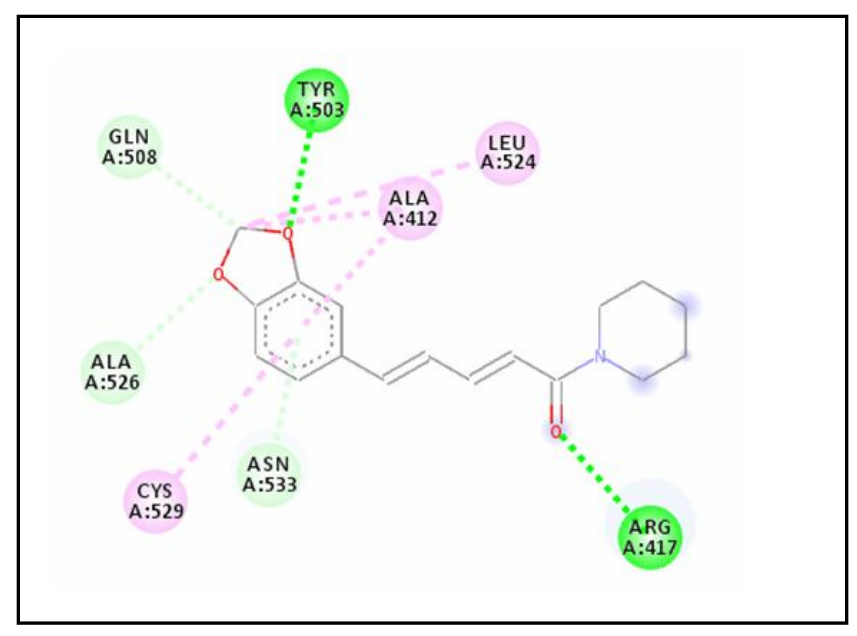

Figure 3: Interaction of piperine on acetylcholinesterase.

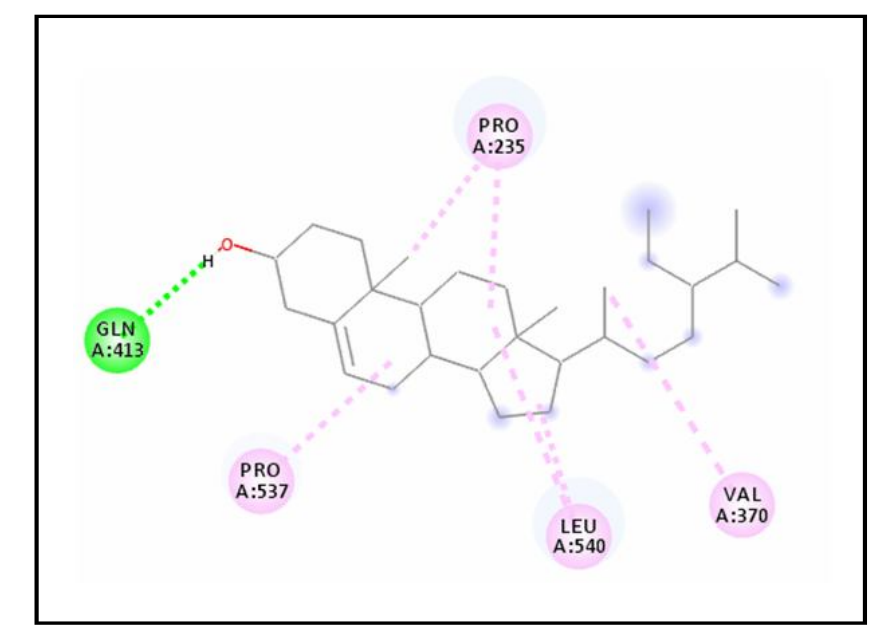

Figure 4: Interaction of beta-sitosterol on acetylcholinesterase. 


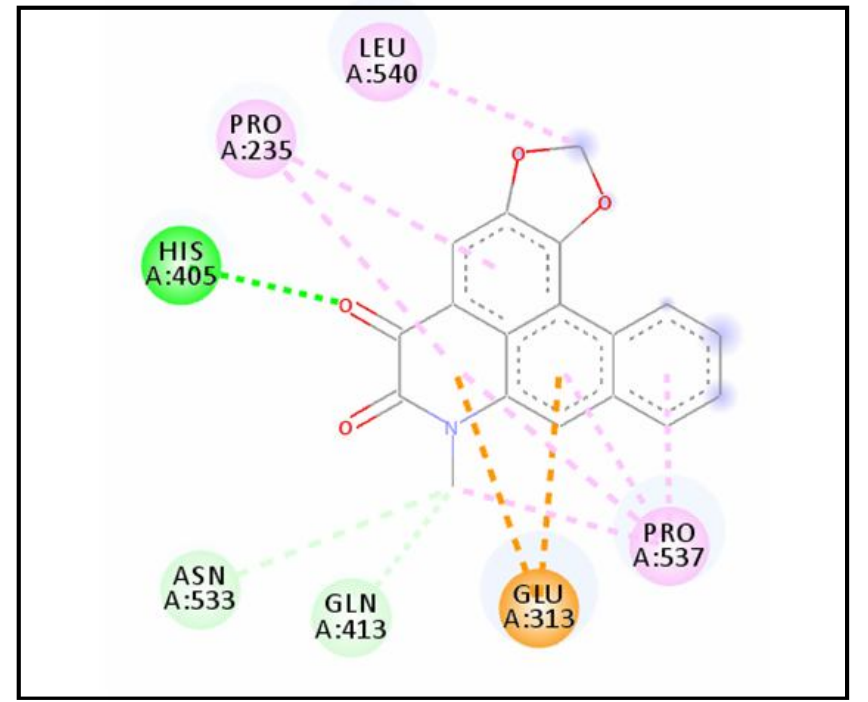

Figure 5: Interaction of cepharadione A on acetylcholinesterase.

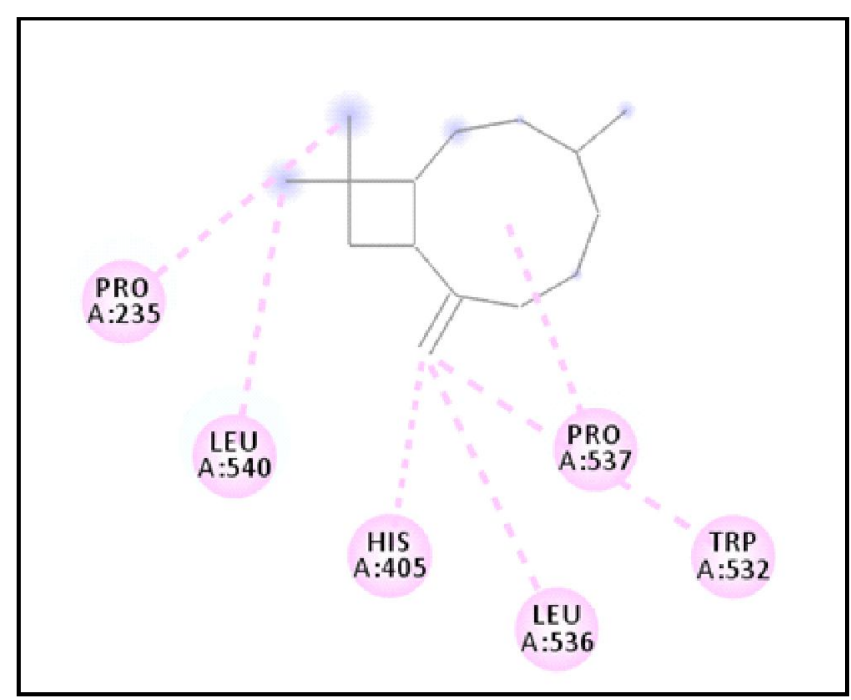

Figure 6: Interaction of beta-caryophyllene on acetylcholinesterase.

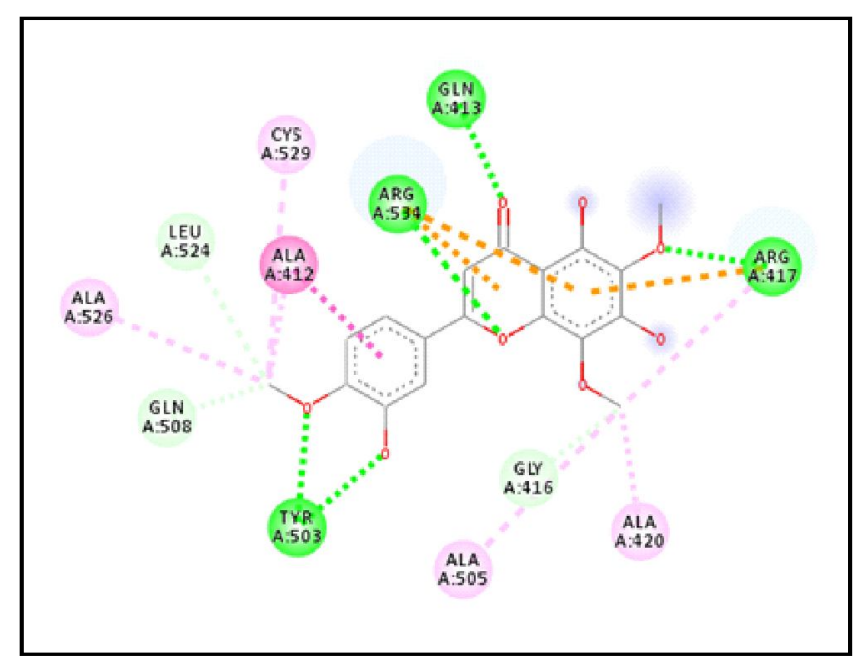

Figure 7: Interaction of acerosin on acetylcholinesterase.

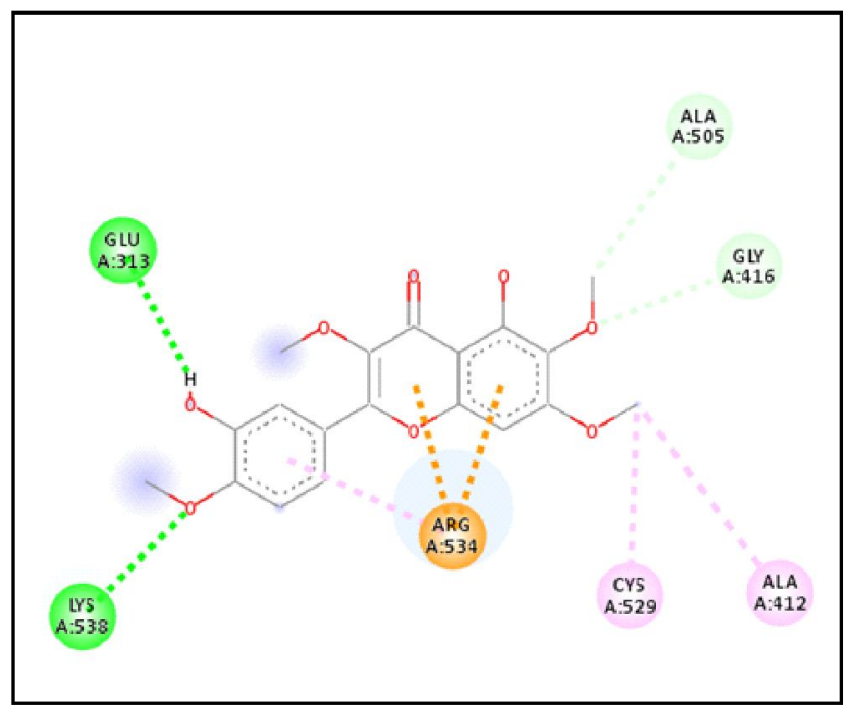

Figure 8: Interaction of casticin on acetylcholinesterase.

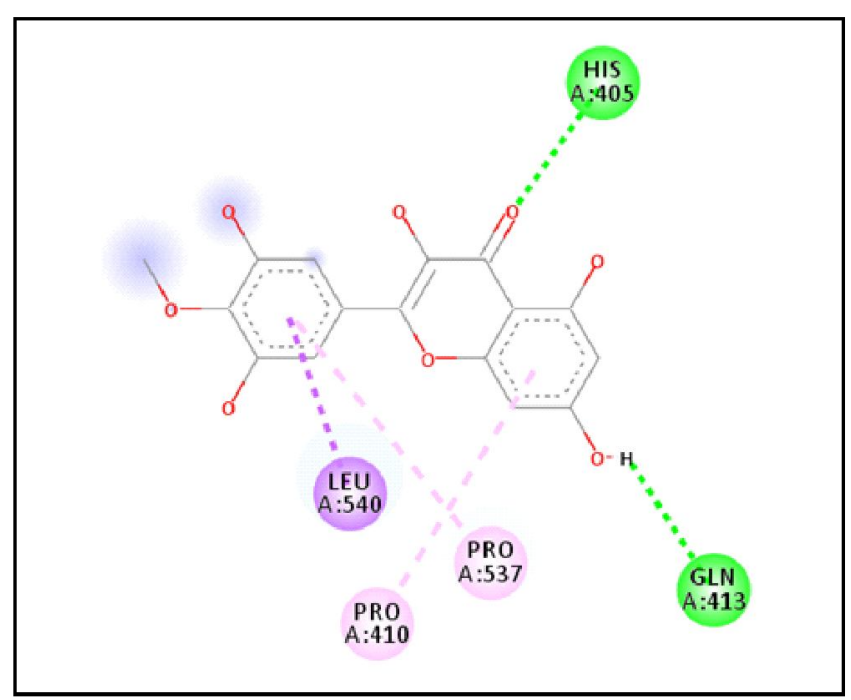

Figure 9: Interaction of mearnsetin on acetylcholinesterase.

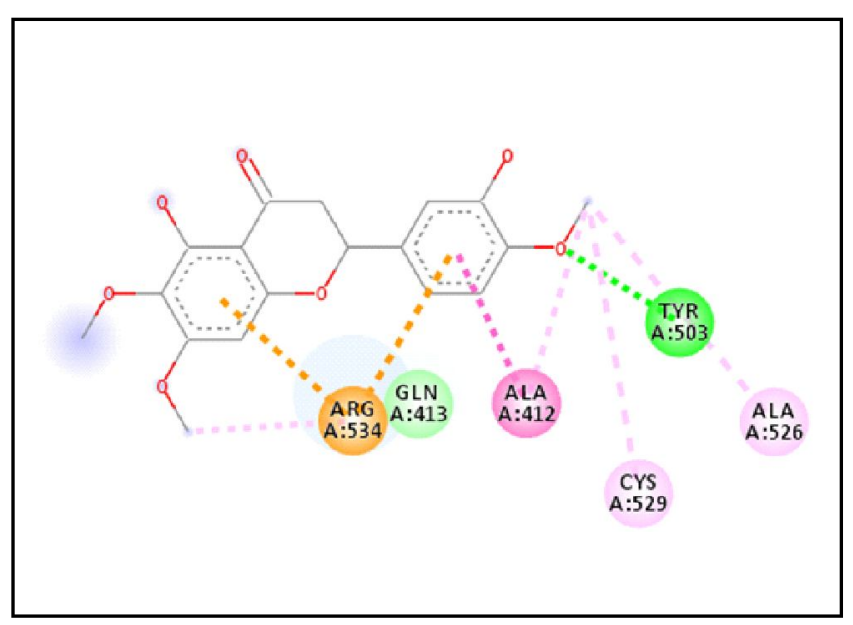

Figure 10: Interaction of 5,3'-dihydroxy-6,7,4'-trimethoxyflava none on acetylcholinesterase. 


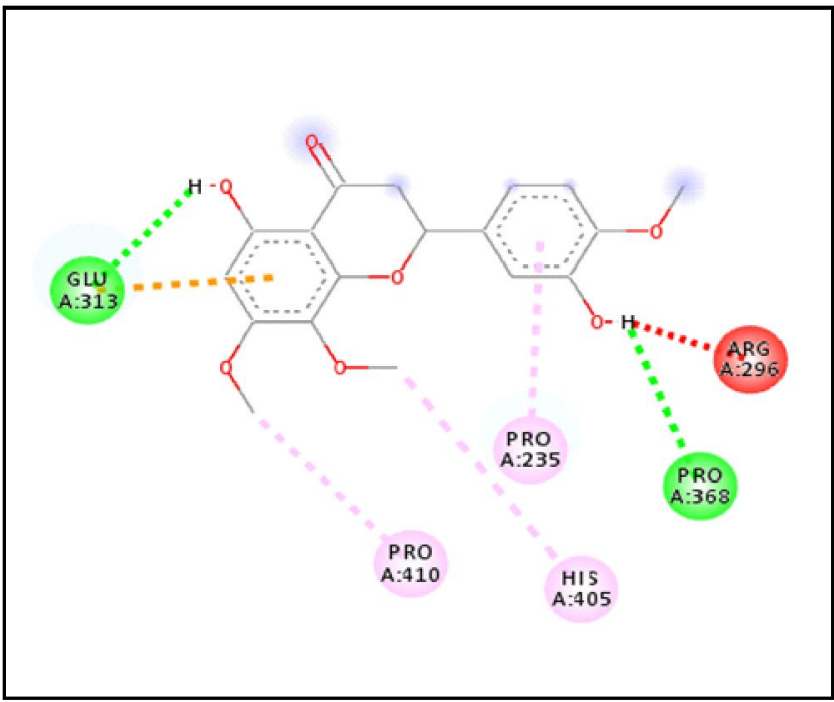

Figure 11: Interaction of 5,3'-dihydroxy-7,8,4'-trimethoxyflava none on acetylcholinesterase.

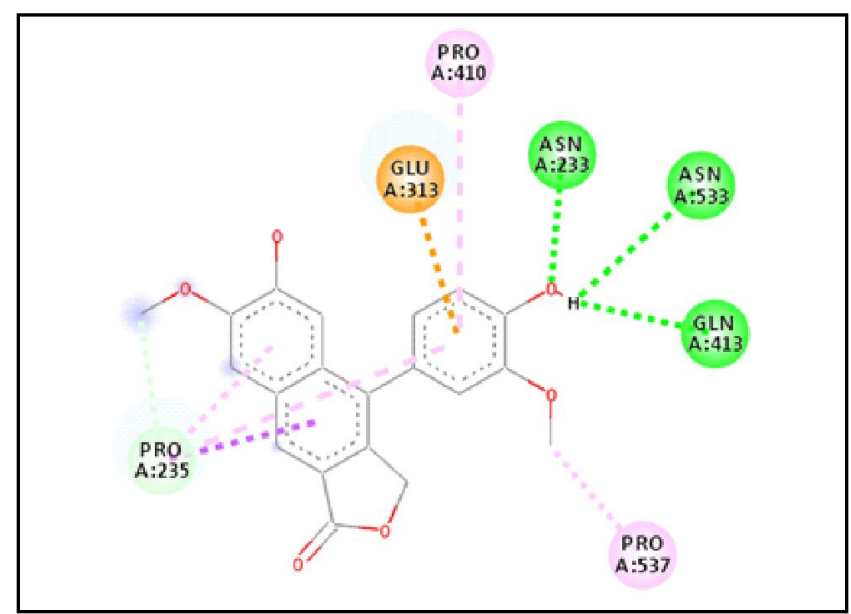

Figure 12: Interaction of detetrahydroconidendrin on acetyl cholinesterase.

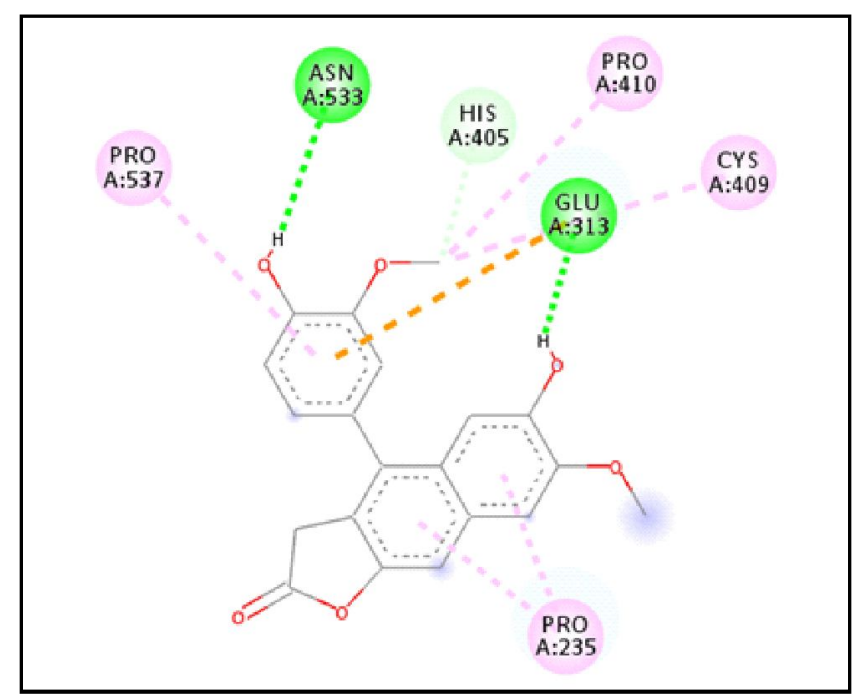

Figure 13: Interaction of negundin A on acetylcholinesterase.

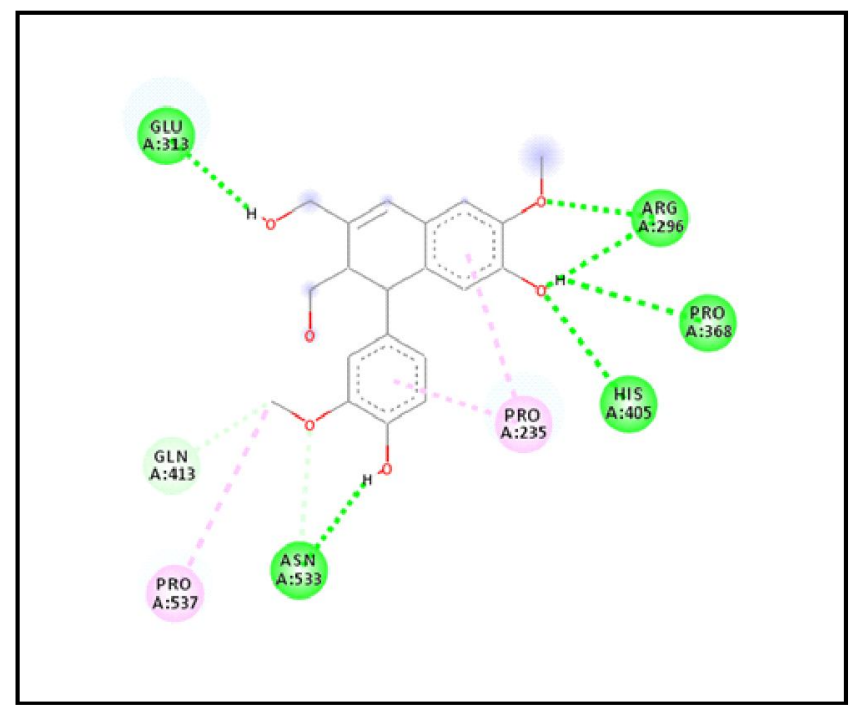

Figure 14: Interaction of negundin $B$ on acetylcholinesterase.

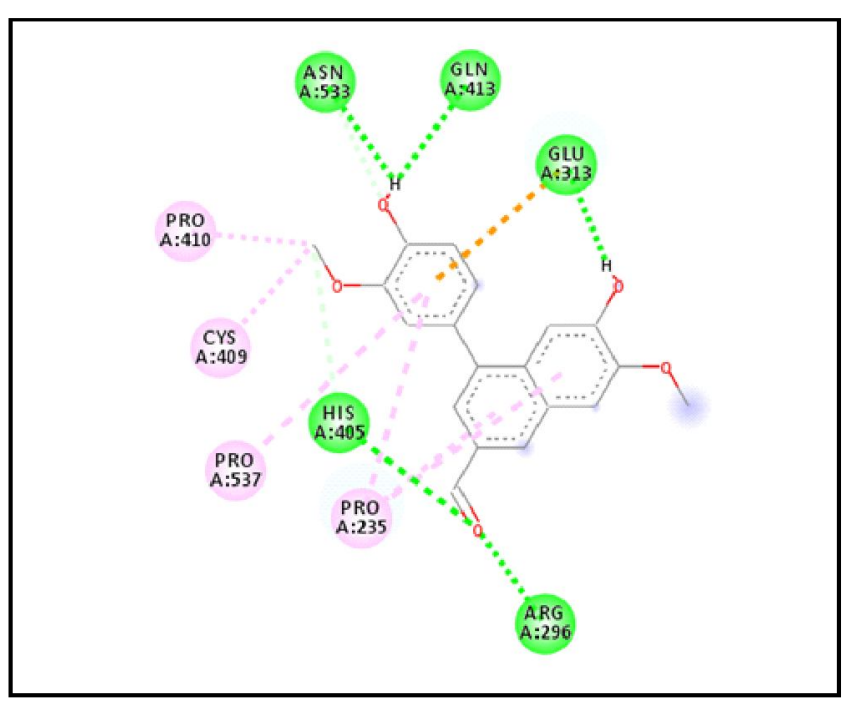

Figure 15: Interaction of vitrofolal $E$ on acetylcholinesterase.

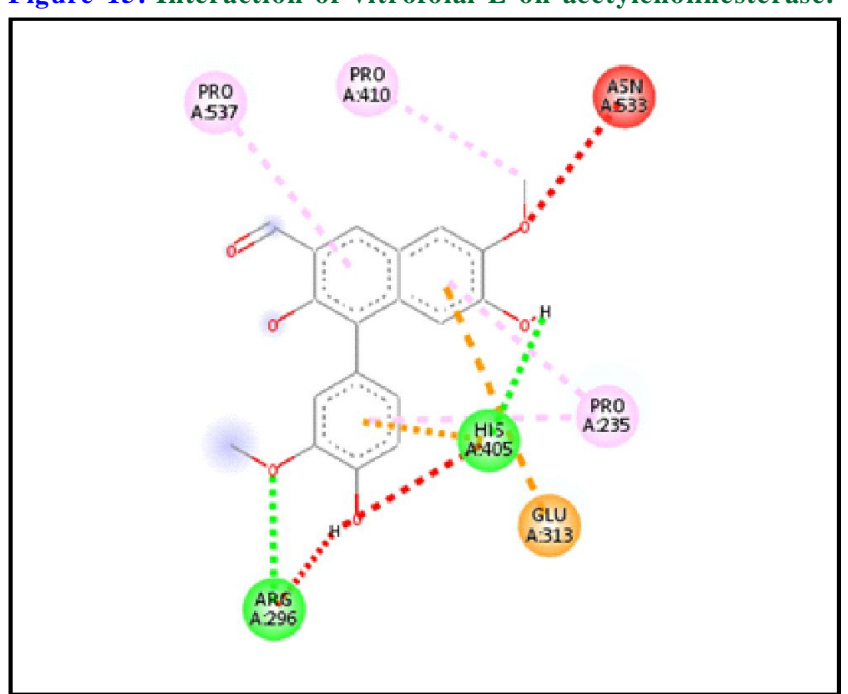

Figure 16: Interaction of vitrofolal $F$ on acetylcholinesterase. 

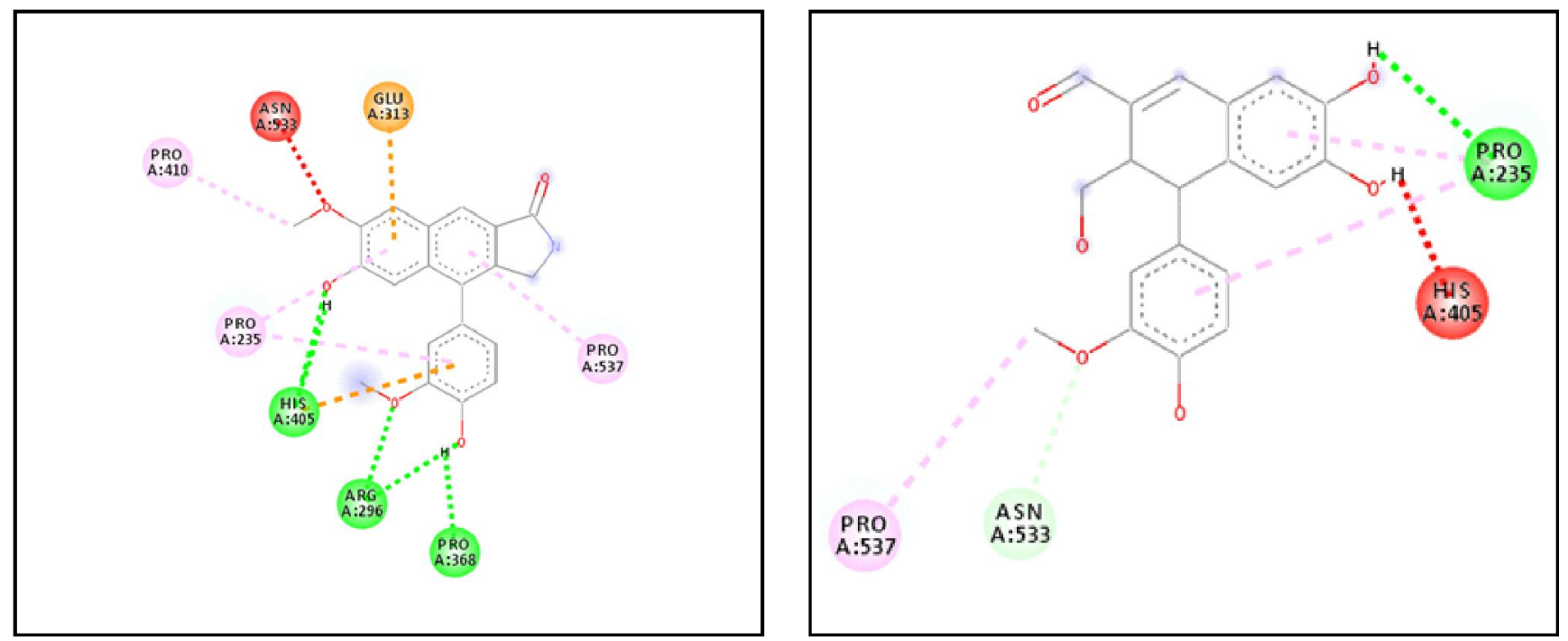

Figure 17: Interaction of vitedoamine $A$ on acetylcholines terase.

Figure 20: Interaction of vitexdoin A on acetylcholinesterase.

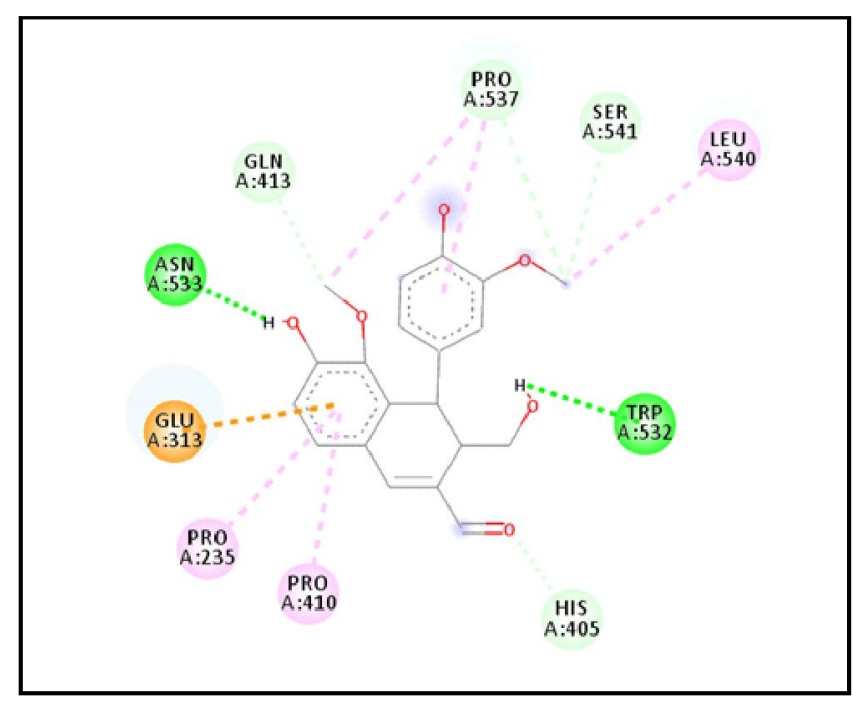

Figure 18: Interaction of vitedoin $A$ on acetylcholinesterase.

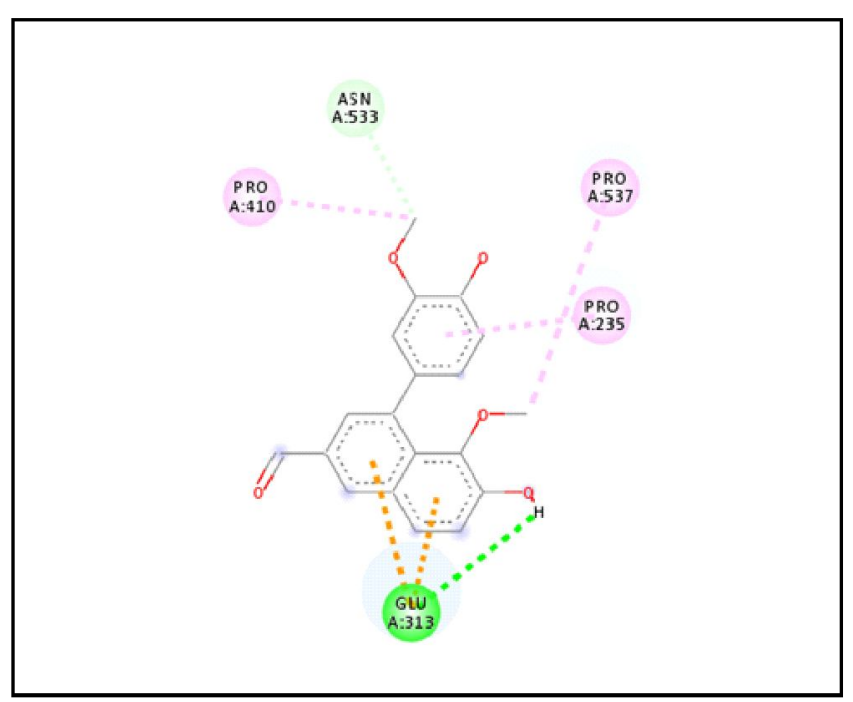

Figure 21: Interaction of vitexdoin $B$ on acetylcholinesterase.

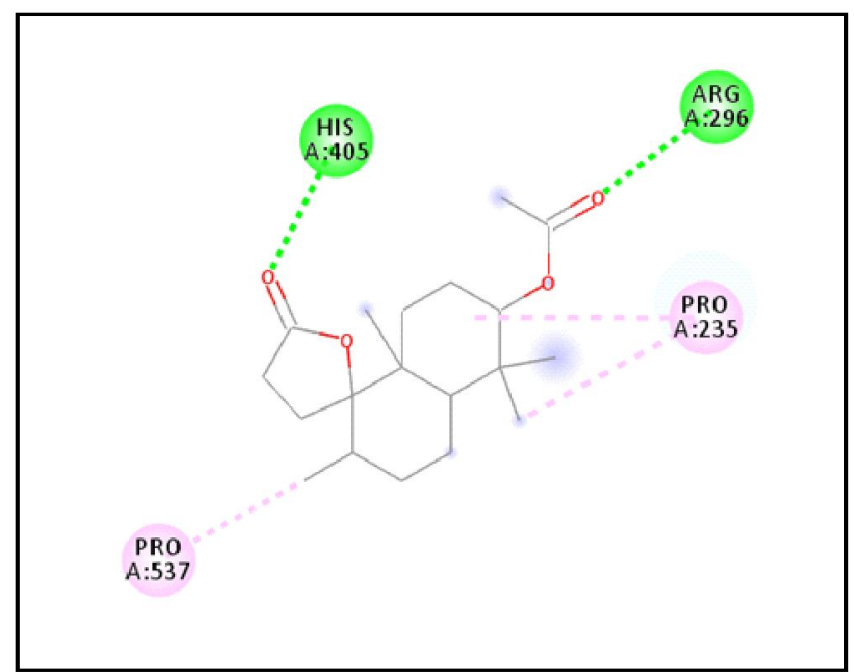

Figure 19: Interaction of vitedoin $B$ on acetylcholinesterase.

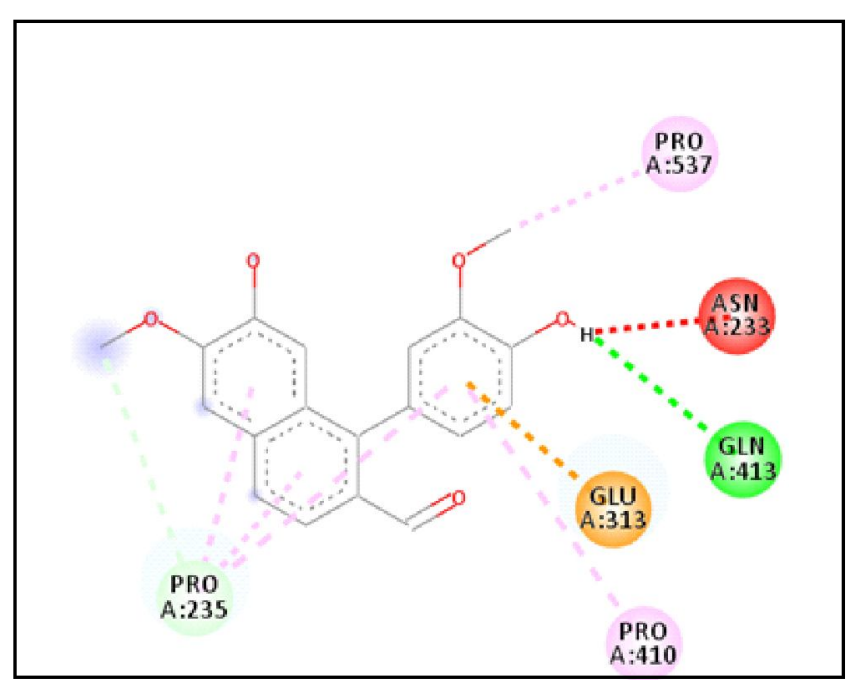

Figure 22: Interaction of vitexdoin $\mathrm{C}$ on acetylcholinesterase. 


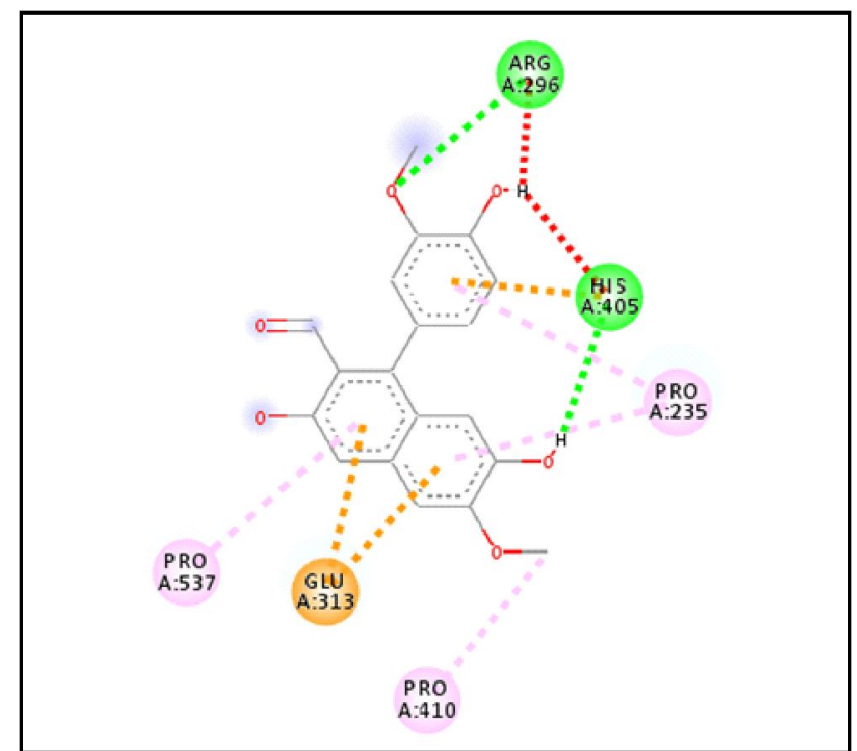

Figure 23: Interaction of vitexdoin D on acetylcholinesterase.

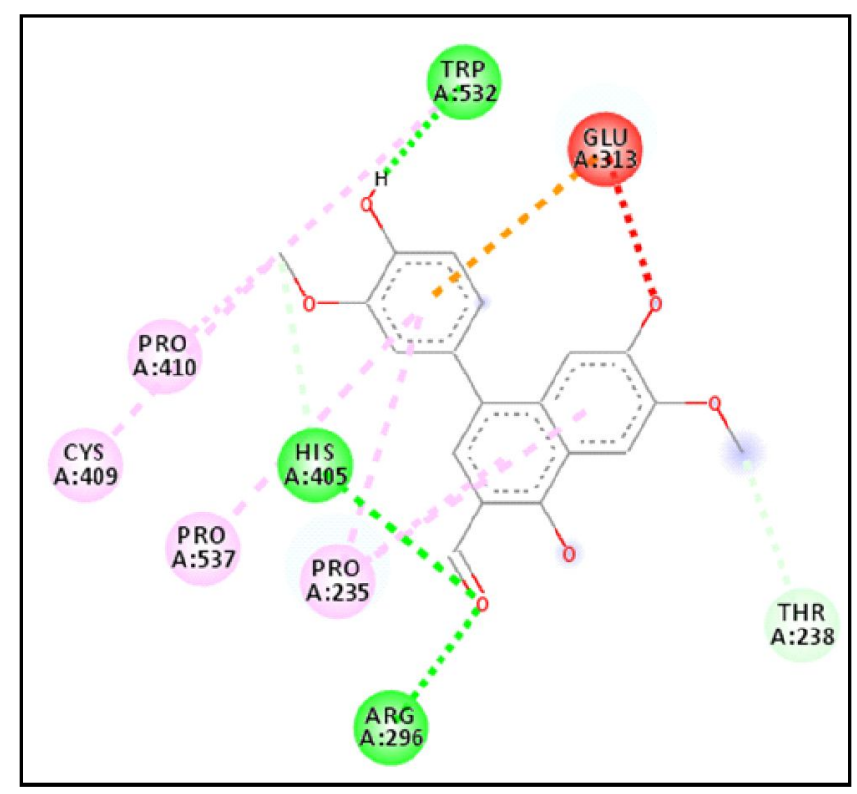

Figure 24: Interaction of vitexdoin $\mathbf{E}$ on acetylcholinesterase.

\subsection{ADMET properties}

ADMET properties of the compounds interact with the absorption, distribution, metabolism, excretion and toxicity in and across the human body. ADMET defines the pharmacokinetic properties of the drug molecule and it is very important in assessing its pharmacodynamic activity. Rivastigmine is used as control drug for comparison. Rivastigmine showed BBB, HIA, In vitro Caco-2 permeability, distribution and non-substrate of CYP450 2C9 values of $0.99,0.99,0.77,0.82$ and 0.84 . Other compounds like piperine, beta-Sitosterol, negundin $\mathrm{B}$, vitedoin $\mathrm{A}$ and vitexdoin $\mathrm{B}$ showed significant ADME values (Table 5). From the toxicity analysis, AMES toxicity and mutagenicity of the compounds were determined. Al the compounds were found to be non-mutagenic and all the compounds except cepharadione A were non-AMES toxic.

\section{Discussion}

Reduced levels of acetylcholine (Ach) and the loss of cholinergic neurons in the brain are linked to the Alzheimer's disease (AD). Ach was the first neurotransmitter found in the central nervous system, and it transmits synaptic signals to all autonomic ganglia, including the neuromuscular junction and synapses. The signal transmission between preganglionic sympathetic and parasympathetic neurons in the autonomic nervous system is regulated by Ach. It is also responsible for the stimulation of muscles, including those of the gastrointestinal tract. The loss of Ach function has been linked to the progression of Alzheimer's disease (Kareti and Pharm, 2020). Natural neurotransmission is hampered by acetylcholinesterase (AChE), an enzyme that breaks down the neurotransmitter Ach into acetate and choline. According to the cholinergic theory of illness, inhibiting AChE activity may be one of the more practical approaches to symptomatic treatment of $\mathrm{AD}$. AChE is one of the most important targets in the fight against Alzheimer's disease (Giacobini, 2004). Thus, AChE is used as the target protein in the present study. The 3D structure of the protein was downloaded from protein databank. The active sites of the proteins were identified by using CASTp online server. Since active sites are the functional sites of the proteins, it is necessary for a ligand docking to be on the binding sites. To evaluate this ideology, ligand interactions on binding sites of target proteins was examined using Discovery studio visualizer 2020 .

P. betle and V. negundo were plants used for the study. P. betle, also known as betel leaf, is a plant with heart-shaped leaves. Piperaceae, also known as the pepper family, is a large flowering plant family found in tropical and subtropical regions of the world. P. betle is a native of Malaysia's central and eastern regions. India, Malaysia, Indonesia, Sri Lanka, the Philippines, China and Vietnam are all home to this species. Climbing herbs and shrubs make up the majority of the plants in this genus. Piper is the only genus in this family of commercial value. P. betle or Paan's leaves, fruits and roots are stimulant, carminative, antiseptic, and used to treat malaria. Antiseptic, antioxidant, analgesic, antibacterial, cardiotonic, antispasmodic, expectorant, tonic, carminative, contraceptive and litholytic properties are all found in betel leaf. An aromatic volatile oil is found in betel leaves. This essential oil has antihypertensive, anticardiac, antirespiratory, and cardiotonic properties (Baviskar et al., 2017; Dwivedi and Tripathi, 2014).

The Five-Leaved Chaste Tree (V. negundo) is a medicinal deciduous shrub with five leaves. It is a native of India, but it can also be found in the Philippines, Bangladesh, Sri Lanka, China and Japan. Ayurveda, Homeopathy, Unani, Allopathy and Siddha use various parts of the tree for medicinal purposes, including leaves, seeds, leaf oil, fruits and roots. It is used to treat headaches, skin irritations, bruises, inflammation, asthmatic pains, and both male and female sexual and reproductive issues. Leaves are used to treat inflammatory swellings of the joints caused by acute rheumatism, as well as swellings of the testes caused by gonorrhoeal epididymitis and orchitis. During a headache, a paste of leaves is added to the temples. The juice of the leaves was applied topically to wounds and ulcers to remove foul smelling discharge. Leaves were also be useful as muscle relaxants, pain relievers, antianxiety, antiasthmatic, and phlegm reducers (Basri et al., 2014; Nishtha and Kaur, 2020). As these plants enhance the immune system and prevents from several disorders, these plants can also be used as immuno-stimulants. 
Phytochemical compounds present in these plants were identified by using KNApSAck database. Total of 42 compounds were identified 34 compounds showed druglikeness based on the Lipinski's Rule of Five (RO5). Molecular docking was performed and compounds showing highest binding energy, i.e., >-7 Kcal $/ \mathrm{mol}$ was selected for further analysis. Nearly, 22 compounds showed higher binding energies. All the compounds except betacaryophyllene showed $\mathrm{H}$-bond formation on binding sites of the target protein (AChE). From the ADMET analysis, all the compounds showed significant ADME properties on comparison with rivastigmine. Cepharadione A was found to be non-AMES toxic.

\section{Conclusion}

From the analysis, 20 compounds were found to be significant and possess good ADMET properties. Piperine present in P. betle and beta-Sitosterol, beta-Caryophyllene, Acerosin, Casticin, Mearnsetin, 5,3'-Dihydroxy-6,7,4'-trimethoxyflavanone, 5,3'Dihydroxy-7,8,4'-trimethoxyflavanone, Detetrahydroconidendrin, Negundin A, Negundin B, Vitrofolal E, Vitrofolal F, Vitedoamine A, Vitedoin A, Vitedoin B, Vitexdoin A, Vitexdoin B, Vitexdoin C, Vitexdoin D,Vitexdoin E present in V. negundo were identified to be the effective acetylcholinesterase inhibitors. Thus, these compounds can be developed as potent drugs and immuno-stimulants for the treatment of Alzheimer's disease.

\section{Acknowledgements}

The author is thankful to the Deanship of Scientific Research, Prince Sattam bin Abdulaziz University, Al-Kharj, Saudi Arabia for the support in conducting the research and publishing this report

\section{Conflict of interest}

The author declares that there are no conflicts of interest relevant to this article.

\section{References}

Basri, F.; Sharma, H.P.; Firdaus, S.; Jain, P. and Ranjan, A. (2014). A review of ethnomedicinal plant- V. negundo Linn. Int. J. Adv. Res., 2:882 894

Baviskar, H.P.; Dhake, GT.; Kasai, M.A.; Chaudhari, N.B. and Deshmukh, T.A. (2017) Review of Piper Betle. Res. J. Pharmacogn. Phytochem., 9:128. https://doi.org/10.5958/0975-4385.2017.00024.3

Cheng, F.; Li, W.; Zhou, Y.; Shen, J.; Wu, Z.; Liu, G.; Lee, P.W. and Tang, Y. (2012) Admet SAR: A comprehensive source and free tool for assessment of chemical ADMET properties. J. Chem. Inf. Model., 52:11, 30993105 https://doi.org/10.1021/ci300367a

D'Andrea, M.R. (2005). Add Alzheimer's disease to the list of autoimmune diseases. Med. Hypotheses, 64:458-463. https://doi.org/10.1016/ j.mehy.2004.08.024

Daina, A.; Michielin, O. and Zoete, V. (2017). SwissADME: A free web tool to evaluate pharmacokinetics, druglikeness and medicinal chemistry friendliness of small molecules. Sci., Rep., 7, 42717. https://doi.org/ $10.1038 /$ srep42717
Dallakyan, S. and Olson, A.J. (2015). Small-molecule library screening by docking with PyRx. Methods Mol. Biol., https://doi.org/10.1007/ 978-1-4939-2269-7_19

Das, S. (2017). Prediction of anti-Alzheimer's activity of flavonoids targeting acetylcholinesterase in silico. Phytochem. Anal., 28:324331. https://doi.org/10.1002/pca.2679

Dwivedi, V. and Tripathi, S. (2014). Review study on potential activity of Piper betle. J. Pharmacogn. Phytochem., 3(4):93-98.

Giacobini, E.(2004). Cholinesterase inhibitors: New roles and therapeutic alternatives. Pharmacol. Res., 50:433-440. https://doi.org/10.1016/ j.phrs.2003.11.017

Kareti, S.R. and Pharm, S.M. (2020). In silico molecular docking analysis of potential anti-Alzheimer's compounds present in chloroform extract of Carissa carandas leaf using gas chromatography MS/MS Curr. Ther. Res. Clin. Exp., 93. https://doi.org/10.1016/j. curtheres. 2020.100615

Lane, C.A.; Hardy, J. and Schott, J.M. (2018). Alzheimer's disease. Eur. J. Neurol. 25:59-70. https://doi.org/10.1111/ene.13439

Lipinski, C.A.; Lombardo, F.; Dominy, B.W. and Feeney, P.J. (2012). Experimental and computational approaches to estimate solubility and permeability in drug discovery and development settings. Adv. Drug Deliv. Rev., 64:4-17.https://doi.org/10.1016/j.addr.2012.09.019

Nishtha, Kaur, R. (2020). Phytochemical investigations and therapeutic potential of Vitex negundo: A review. Eur. J. Mol. Clin. Med., 17:2340

Prince, M.; Wimo, A.; Guerchet, M.; Gemma-Claire, A.; Wu, Y.-T. and Prina, M. (2015). World Alzheimer report 2015: The global impact of dementia - An analysis of prevalence, incidence, cost and trends. Alzheimer's Dis. Int., 84. https://doi.org/10.1111/j.0963-7214.2004.00293.x

Rédei, G.P. (2008). PubChem, in: Encyclopedia of Genetics, Genomics, Proteomics and Informatics. https://doi.org/10.1007/978-1-40206754-9 13806

S. Shanthipriya, S.S. and Doss, D.V.A. (2012). Active site prediction and targeting bipolar disorder through molecular docking techniques on protein kinase epsilon. Int. J. Sci. Res., 6:33-35. https://doi.org/10.15373/ 22778179/june2013/11

Sanjay Prasad, S. and Shanthi, S.(2020). Identification of angiotensin converting enzyme (ACE) inhibiting phytochemical compounds from Aegle marmelos, Euphorbia hirta, Senna auriculata, Ocimum tenuiflorum and Hibiscus rosasinensis by In silico. International Journal of Pharma and Biosciences, 11:79-85. https://doi.org/ 10.22376/ijpbs.2020.11.3.b

Schnabel, J. (1993). New Alzheimer's therapy suggested. Science (80). 260:1719-1720. https://doi.org/10.1126/science.8323582

Tian, W.; Chen, C.; Lei, X.; Zhao, J. and Liang, J. (2018). CASTp 3.0: Computed atlas of surface topography of proteins. Nucleic Acids Res., 46:363367 https://doi.org/10.1093/nar/gky473 